\title{
Editorial \\ Organic Farming Provides a Blueprint to Improve Food Quality, Safety and Security
}

Carlo Leifert ${ }^{1,2}$ (D)

check for

updates

Citation: Leifert, C. Organic Farming

Provides a Blueprint to Improve

Food Quality, Safety and Security.

Agronomy 2022, 12, 631. https://

doi.org/10.3390/agronomy12030631

Received: 20 January 2022

Accepted: 25 February 2022

Published: 4 March 2022

Publisher's Note: MDPI stays neutral with regard to jurisdictional claims in published maps and institutional affiliations.

Copyright: (C) 2022 by the author. Licensee MDPI, Basel, Switzerland. This article is an open access article distributed under the terms and conditions of the Creative Commons Attribution (CC BY) license (https:// creativecommons.org/licenses/by/ $4.0 /)$.
1 SCU Plant Science, Southern Cross University, Military Rd., Lismore, NSW 2480, Australia; carlo.leifert@gmail.com; Tel.: +44-1434-634929

2 Department of Nutrition, Institute of Basic Medical Sciences, University of Oslo, 0372 Oslo, Norway

The increasing reliance on non-renewable resources (in particular, mineral nitrogen, phosphorus and potassium fertilizers and synthetic chemical pesticides) to sustain current productivity levels of agriculture are of growing concern, because these inputs have substantial negative environmental impacts and may become too expensive and/or unavailable in the future [1-3].

Organic farming standards prohibit (mineral $\mathrm{N}$-fertilizer and pesticides) or restrict $(\mathrm{P}, \mathrm{K}$ and other micronutrient fertilizers) the use of these non-renewable resources, but yields in organic farming were reported to be $\sim 25-30 \%$ lower than in intensive conventional farming systems [4].

There is now substantial evidence from meta-analyses of comparative food composition data that organic crops, dairy and meat products have a more favorable nutritional composition (e.g., higher mineral, omega-3 fatty acid, phenolic/antioxidant and/or mineral concentrations, but lower pesticide and/or heavy metals residue levels) than their conventional comparators [5-7]. Additionally, a range of observational/cohort studies have reported that high levels of organic food consumption are associated with a lower incidence of certain chronic diseases, including overweight/obesity, metabolic syndrome and cancer [8].

In this context, the aim of the review article by Rempelos et al. [9] in the Special Issue of Agronomy on "Integrated Soil, Crop and Human Nutrition and Health Management in organic Agriculture" was to critically evaluate evidence from:

- Long-term, factorial field experiments and retail surveys designed to provide a mechanistic understanding of how organic soil and crop management practices produce healthy crops and deliver the nutritional quality gains identified in meta-analyses [5-7]; and

- Animal and human dietary intervention studies designed to identify the main nutritional drivers (e.g., lower dietary intake of pesticides and/or toxic metals; increased intake of antioxidants/phenolics and/or mineral micronutrients) for health benefits linked to organic food consumption [8].

Organic farming minimizes negative impacts of agricultural intensification

With regard to crop health and nutritional quality, Rempelos et al. [9] conclude that "there is now substantial evidence that the use of:

- Monoculture and short rotations can increase crop species-specific weed, pest and disease pressure and may lead to (a) greater dependence on synthetic chemical pesticides, (b) higher pesticide residues being present in crops, and (c) a greater risk of Fusarium infection and mycotoxin contamination of cereal grains;

- $\quad$ Mineral phosphorus fertilizer can (a) reduce mycorrhizal development on roots and thereby negatively affect mineral micronutrient uptake and resistance against soil-borne diseases, and (b) increase cadmium concentrations in crops; 
- Mineral nitrogen fertilizer is associated with (a) a reduction in crop resistance, (b) lower concentrations of nutritionally desirable phenolics and other resistance-related phytochemicals/antioxidants in crops, and (c) increases the risk of Fusarium infection and mycotoxin contamination in cereal grains;

- $\quad$ Synthetic chemical pesticides in agriculture is responsible for chronic dietary pesticide exposure and may reduce concentrations of certain nutritionally desirable phytochemicals/antioxidants and mineral micronutrients in crops; and

- Modern short-straw cereal varieties, results in crops that are (a) less competitive against weeds and more susceptible to certain diseases (e.g., Fusarium, Septoria), (b) have lower grain protein and mineral micronutrient concentrations, and (c) more susceptible to Fusarium infection and associated mycotoxin contamination."

However, it is important to point out that data from long-term, factorial field experiments that quantified the relative impact of agronomic practices and variety choice on crop health and nutritional composition are only available for a limited number of crops and pedoclimatic environments [9]. In addition, Rempelos et al. [9] describe that recent retail surveys of wheat, flour and table grapes suggest that variety choice/genetics, post-harvest storage and processing, and supply chain parameters can have a larger effect on the nutritional composition of crops than agronomic parameters such as fertilization and crop protection regimes.

The Special Issue of Agronomy on "Integrated Soil, Crop and Human Nutrition and Health Management in Organic Agriculture" therefore aims to address these gaps in knowledge and facilitate the publication/dissemination of additional studies designed to compare and/or improve:

- $\quad$ organic and/or non-organic (including regenerative) crop production systems

- $\quad$ specific crop management practices (e.g., rotation designs, tillage systems, crop protection methods, fertilization regimes, and varieties/cultivar selection)

with respect to one or more of the following parameters: (1) crop health, yield and yield stability, quality and safety parameters, (2) resource use efficiency, (3) environmental impacts/carbon footprints, and/or (4) cost of production, and/or (5) trade-offs between these factors.

\section{Observational studies linked organic food consumption to health benefits}

Rempelos et al. [9] summarize results from human cohort studies which suggest that there may be significant positive health outcomes from organic food consumption. Specifically, they review studies reporting positive associations between organic food consumption and reduced incidence of pre-eclampsia (a leading cause of maternal and foetal morbidity and mortality for which inflammation and obesity are risk factors), eczema in infants, congenital disorders (hypospadias), middle ear infections, cancer, obesity/overweight and metabolic syndrome. They note that these cohort studies do not prove causality and need to be interpreted with caution, due to (a) the uncertainties associated with self-reporting-based estimates of organic and conventional food consumption, and (b) the confounding effects of well documented differences in lifestyles and diets between organic and conventional food consumers. However, the available cohort data demonstrate the potential to improve public health by switching to organic food consumption. For example, a $40 \%$ reduction in obesity alone (which was reported to be associated with organic food consumption in a large French cohort study) would have a substantial impact on public health and healthcare costs [10].

Rempelos et al. [9] also reviewed circumstantial evidence from observational and animal and human dietary intervention studies which indicates that (1) lower pesticide exposure and higher antioxidant intake may be the main drivers for health benefits from organic food consumption, and (2) that health impacts may be linked to effects on endocrine and immune system parameters. Most importantly,

- a recent human dietary intervention study reported that (1) total pesticide intake with conventional food is similar to dietary intake of the essential mineral micronutrient $\mathrm{Cu}$, 
and (2) a large number of pesticides are suspected or confirmed endocrine disrupting chemicals and may therefore have effects at very low concentrations [11];

- observational studies comparing (1) human cohorts with high and low pesticide intakes and (2) high and low organic food consumption reported association between high pesticide and low organic food consumption, and negative health impacts for a similar range of diseases including obesity, metabolic syndrome, lymphomas, breast cancer, and hypospadias [8,11]; and

- factorial dietary intervention studies with rats identified dietary pesticide and (poly) phenolic intakes as important explanatory variables/drivers for differences in hormonal balances and immune-system responsiveness in rats raised on feeds made from crops produced with organic versus conventional fertilization and crop protection regimes $[12,13]$.

However, due to the lack of data from clinical trials, they conclude: "Although organic food consumption was linked to positive health impacts in observational studies, one important limitation in the currently available evidence is that controlled clinical trials, to confirm and provide a mechanistic understanding of the positive health impacts of organic food consumption reported in observational studies, have not yet been carried out".

The need to change diets and the way food is produced to increase Food Security and Public Health

Rempelos et al. [9] also highlight emerging evidence that:

- health benefits linked to organic food consumption may be greater for consumers with healthy diets (e.g., individuals that follow current nutritional guidelines to reduce meat and/or increase wholegrain, fruit and vegetable consumption); and

- the adoption of both healthier diets and organic food production methods may have synergistic effects with respect to reducing environmental impacts and increasing food quality, safety and security, and public health.

These conclusions/hypotheses are supported by a recent study by Frehner et al. [14] who estimated that reducing meat production and changing to more plant-based diets can reduce environmental impacts by up to $51 \%$ and increase diet quality by up to $57 \%$, while changing to organic farming standards would lead to an increase in the amount of land area required for food production, unless there is also diet change.

It is important to note that both studies $[9,14]$ highlight that organic produce is more expensive and that circularity land use principles (e.g., minimizing intensive conventional soya, maize and cereals to produce feeds for intensive feed-lot red meat production systems), in addition to diet change and organic production methods, would be required to substantially minimize environmental impacts and increase the sustainability of the food system. Frehner et al. [14] point out that shorter supply chains and reducing food waste will also contribute to improve sustainability, but to a lesser extent.

Overall, the evidence presented by Rempelos et al. [9] supports the underlying philosophy/hypothesis of organic farming-“healthy soils generate healthy crops which lead to healthy livestock and humans" - which was formulated by Sir Albert Howard and other organic farming pioneers more than 80 years ago.

Funding: No external funding was received by the author.

Acknowledgments: The author gratefully acknowledges support for the proof reading of the editorial by Catherine Leifert.

Conflicts of Interest: The author declares no conflict of interest.

\section{References}

1. Tilman, D.; Cassman, K.G.; Matson, P.A.; Naylor, R.; Polasky, S. Agricultural sustainability and intensive production practices. Nature 2002, 418, 671-677. [CrossRef] [PubMed]

2. Cordell, D.; Drangert, J.-O.; White, S. The story of phosphorus: Global food security and food for thought. Glob. Environ. Chang. 2009, 19, 292-305. [CrossRef] 
3. Cucina, M.; Regni, L. New Advances on Nutrients Recovery from Agro-Industrial and Livestock Wastes for Sustainable Farming. Agronomy 2021, 11, 2308. [CrossRef]

4. Seufert, V.; Ramankutty, N.; Foley, J.A. Comparing the yields in organic and conventional agriculture. Nature 2012, 485, 229-234. [CrossRef] [PubMed]

5. $\quad$ Baranski, M.; Srednicka-Tober, D.; Volakakis, N.; Seal, C.; Sanderson, R.; Stewart, G.B.; Benbrook, C.; Biavati, B.; Markellou, E.; Giotis, H.; et al. Higher antioxidant and lower cadmium concentrations and lower incidence of pesticide residues in organically grown crops: A systematic literature review and meta-analysis. Br. J. Nutr. 2014, 112, 794-811. [CrossRef] [PubMed]

6. Srednicka-Tober, D.; Baranski, M.; Seal, C.J.; Sanderson, R.; Benbrook, C.; Steinshamn, H.; Gromadzka-Ostrowska, J.; Rembiałkowska, E.; Skwarło-SońEta, K.; Eyre, M.; et al. Higher PUFA and omega-3 PUFA, CLA, $\alpha$-tocopherol and iron, but lower iodine and selenium concentrations in organic milk: A Systematic Literature Review and Meta- and Redundancy Analyses. Br. J. Nutr. 2016, 115, 1043-1060. [CrossRef] [PubMed]

7. Srednicka-Tober, D.; Marcin Barański, M.; Seal, C.J.; Sanderson, R.; Benbrook, C.; Steinshamn, H.; Gromadzka-Ostrowska, J.; Rembiałkowska, E.; Skwarło-Sońta, K.; Eyre, M.; et al. Composition differences between organic and conventional meat; A systematic literature review and meta-analysis. Br. J. Nutr. 2016, 115, 994-1011. [CrossRef] [PubMed]

8. Vigar, V.; Myers, S.; Oliver, C.; Arellano, J.; Robinson, S.; Leifert, C. A Systematic Review of Organic Versus Conventional Food Consumption: Is There a Measurable Benefit on Human Health? Nutrients 2020, 12, 7. [CrossRef] [PubMed]

9. Rempelos, L.; Baranski, M.; Wang, J.; Adams, T.N.; Adebusuyi, K.; Beckman, J.J.; Brockbank, C.J.; Douglas, B.S.; Feng, T.; Greenway, J.D.; et al. Integrated Soil and Crop Management in Organic Agriculture: A Logical Framework to Ensure Food Quality and Human Health? Agronomy 2021, 11, 2494. [CrossRef]

10. Must, A.; Spadano, J.; Coakley, E.H.; Filed, A.E.; Colditz, G.; Dietz, W. The disease burden associated with overweight and obesity. JAMA 1999, 282, 1523-1529. [CrossRef]

11. Rempelos, L.; Wang, J.; Baranski, M.; Watson, A.; Volakakis, N.; Hoppe, H.-W.; Kühn-Velten, W.N.; Hadall, C.; Hasanaliyeva, G.; Chatzidimitriou, E.; et al. Diet and food type affect urinary pesticide residue excretion profiles in healthy individuals: Results of a randomized controlled dietary intervention trial. Am. J. Clin. Nutr. 2021, 115, 364-377. [CrossRef]

12. Srednicka-Tober, D.; Baranski, M.; Gromadzka-Ostrowska, J.; Skwarło-Sońta, K.; Rembiałkowska, E.; Hajslova, J.; Schulzova, V.; Cakmak, I.; Ozturk, L.; Królikowski, T.; et al. Effect of crop protection and fertilization regimes used in organic and conventional production systems on feed composition and selected physiological parameters in rats. J. Agric. Food Chem. 2013, 61, 1017-1029. [CrossRef]

13. Baranski, M.; Srednicka-Tober, D.; Rempelos, L.; Hasanaliyeva, G.; Gromadzka-Ostrowska, J.; Skwarło-Sońta, K.; Królikowski, T.; Rembiałkowska, E.; Hajslova, J.; Schulzova, V.; et al. Feed Composition Differences Resulting from Organic and Conventional Farming Practices Affect Physiological Parameters in Wistar Rats-Results from a Factorial, Two-Generation Dietary Intervention Trial. Nutrients 2021, 13, 377. [CrossRef] [PubMed]

14. Frehner, A.; De Boer, I.; Muller, A.; Van Zanten, H.; Schader, C. Consumer strategies towards a more sustainable food system: Insights from Switzerland. Am. J. Clin. Nutr. 2021, nqab401. [CrossRef] [PubMed] 